\title{
PENGARUH STATUS SOSIAL EKONOMI ORANG TUA DAN PRESTASI AKADEMIK TERHADAP MINAT MELANJUTKAN STUDI S2 MAHASISWA FAKULTAS EKONOMI ANGKATAN 2014 UNESA
}

\author{
Nada Ayu Afina \\ Program Studi Pendidikan Ekonomi, Fakultas Ekonomi, Universitas Negeri Surabaya \\ Email: nadaafina@mhs.unesa.ac.id \\ Yoyok Soesatyo \\ Program Studi Pendidikan Ekonomi, Fakultas Ekonomi, Universitas Negeri Surabaya \\ Email: yoyoksoesatyo@unesa.ac.id
}

\begin{abstract}
Abstrak
Tujuan dalam penelitian ini untuk mengidentifikasi pengaruh status sosial ekonomi orang tua dan prestasi akademik mahasiswa terhadap minat melanjutkan studi S2 mahasiswa fakultas ekonomi angkatan 2014 Unesa. Dalam penelitian ini menggunakan pendekatan kuantitatif dengan jenis asosiatif. Teknik sampling dalam penelitian ini yakni simple random sampling. Total sebanyak 270 responden. Teknik pengumpulan data menggunakan kuisioner dan dokumentasi. Hasil dalam penelitian ini adalah (1) adakah pengaruh positif signifikan status sosial ekonomi orang tua terhadap minat melanjutkan studi S2 dan tingkat signifikansinya sebesar $0,000<$ probabilitas 0.05 . (2) adakah pengaruh positif signifikan prestasi akademik mahasiswa terhadap minat melanjutkan studi S2 dan tingkat signifikansinya sebesar $0,000<$ probabilitas 0.05 .
\end{abstract}

Kata Kunci: status sosial ekonomi orang tua, prestasi akademik, minat melanjutkan studi S2.

\section{Abstract}

The purpose of this study was to identify the influence of parents' socio-economic status and student academic achievement on the interest in continuing the S2 study of 2014 faculty of economic faculty students at Unesa.. In this study using a quantitative approach with an associative type. The sampling technique in this study is simple random sampling. Total sample is 270 respondents. The technique of collecting data uses questionnaires and documentation.The results of the study are: (1) There is a positive significant influence of parents' socio-economic status on the interest in continuing S2 studies and a significance level of $0.000<0.05$ probability. (2) There is a positive significant effect of student academic achievement on the interest in continuing S2 studies and a significance level of $0.000<0.05$ probability.

Keywords: Parents' socio-economic status, academic achievement, interest in continuing S2 studies.

\section{PENDAHULUAN}

Sumber daya manusia yang berkualitas sangat dibutuhkan pada era globalisasi pada saat ini. Upaya yang dilakukan dapat dengan mempunyai tingkat pendidikan yang tinggi. Dengan mempunyai SDM yang berkualitas, diharapkan mampu bersaing dan mempersiapkan diri serta mempunyai ilmu pengetahuan sebagai bekal dimasa mendatang.

Dalam mendukung pembangunan suatu negara, pendidikan memiliki peranan penting sehingga dapat suatu bangsa dapat menjadi lebih maju. Melalui pendidikan, setiap orang dapat meningkatkan pengetahuan dasar yang dimiliki, dan mengembangkan kepribadian, baik dalam pendidikan formal dan pendidikan non formal.

Dalam kehidupan bermasyarakat, tingkat pendidikan yang tinggi sangatlah berpengaruh. Dalam bermasyarakat semakin tinggi pendidikan yang ditempuh, semakin dihormati dan diteladani oleh masyarakat. Begitu juga sebaliknya dengan yang tidak mempunyai tingkat pendidikan yang tinggi tentu dalam bermasyarakat akan biasa saja.

Dalam mendidik anak orang tua mempunyai peranan yang penting, karena pendidikan pertama kali yang diterima oleh anak 
berasal dari keluarga terdekat. Dan orang tua juga mempunyai pendorong yang menjadi indikator utama dalam berlangsungnya pendidikan anaknya, yakni status sosial ekonomi.

Dalam membentuk karakter ana

$\mathrm{k}$, yang mempunyai pengaruh besar adalah kondisi sosial ekonomi orang tua. Kesempatan semakin luas bagi yang mempunyai keadaan ekonomi yang cukup untuk mengembangkan potensi pendidikan anaknya. Sedangkan bagi orang tua yang mempunyai keadaan ekonomi yang rendah tentu mempunyai kendala dalam mengembangkan potensi pendidikannya. Dalam ilmu ekonomi disebutkan bahwa semakin besar kebutuhan yang dapat terpenuhi apabila mempunyai pendapatan yang tinggi, sebaliknya kebutuhan tidak dapat terpenuhi dikarenakan mempunyai pendapatan yang rendah. Artinya yakni semakin tinggi pendapatan ekonomi maka fasilitas pendidikan tentu akan terpenuhi.

Menurut (Abdulsyani, 2012) indikator dalam menentukan status sosial ekonomi orang tua terdapat 4 , yaitu tingkat pendapatan, tingkat pendidikan, jenis rumah tinggal, dan kepemilikan fasilitas.

Selain itu, prestasi akademik mahasiswa dapat mempengaruhi mahasiswa dalam minat melanjutkan studi. Dasar indikator untuk mengukur kemampuan mahasiswa adalah prestasi akademik yang diperoleh mahasiswa pada suatu jenjang pendidikan. Yang dimaksud prestasi belajar siswa dapat dikatakan berhasil yakni apabila telah mencapai tujuan yang telah ditetapkan (Muhibbin Syah, 2011).

Keberhasilan mahasiswa di perguruan tinggi, dapat diukur dari penilaian setiap mata kuliah, penilaian semester, dan penilaian prestasi kumulatif. IPK atau indeks prestasi_akademik mahasiswa adalah tolak ukur yang dipakai.

Menurut (Sumadi Suryabrata, 2008) prestasi akademik yakni pencapaian akhir dari hasil belajar dan dinyatakan dalam bentuk simbol tertentu atau angka. Maka dari itu baik siswa maupun orang lain dapat mengetahui prestasi akademik yang telah di capai. Oleh karena itu, prestasi akademik di kampus/ universitas merupakan hasil belajar akhir mahasiswa yang dilihat dari penguasaan pelajaran selama perkuliahan dalam kurun waktu tertentu, sehingga IPK bisa dijadikan hasil belajar akhir.

Universitas negeri di surabaya ada banyak, salah satunya Universitas Negeri
Surabaya atau Unesa. Fenomena saat dalam observasi penelitian mahasiswa saat diwawancarai mengatakan secara garis besar, orang tua mahasiswa mempunyai beragam status sosial. Ada yang kalangan atas, menengah, dan bawah. Kebanyakan mahasiswa di Unesa memiliki status sosial ekonomi orang tua di kalangan menengah, yakni mempunyai presentase $49 \%$, kalangan atas $20 \%$, dan kalangan bawah $31 \%$. Bisa dikatakan demikian karena orang tua mahasiswa tersebut memiliki kemampuan finansial yang berbeda-beda. Dari status sosial ekonomi bermacam-macam ternyata mahasiswa unesa juga memiliki berbagai prestasi akademik. Ada yang berprestasi baik dan juga ada yang buruk. Prestasi akademik mahasiswa dapat berupa IPK yang diperoleh di setiap akhir semester. Terdapat $10 \%$ mahasiswa mempunyai IPK 2,5 - 3,0, 60\% mahasiswa mempunyai IPK 3,0 - 3,5 dan terdapat $40 \%$ mahasiswa mempunyai IPK diatas 3,5 .

Untuk dapat mengembangkan ilmu pengetahuan, peserta didik di berikan peluang di perguruan tinggi. Untuk mendapatkan ilmu pengetahuan yang banyak, harus menempuh pendidikan yang tinggi. Rasa ketertarikan untuk menempuh studi diperguruan tinggi sangat dibutuhkan karena sebagai pendorong untuk melanjutkan studi ke jenjang yang lebih tinggi . Lalu dengan adanya minat dalam diri dapat medorong seseorang untuk melakukan suatu tindakan dan partisipasi didalamnya. Dengan adanya minat, mahasiswa dapat melanjutkan studi S2 dan mereka akan lebih berusaha memasuki perguruan tinggi guna mengembangkan ilmu pengetahuan.

(Sumadi Suryabrata, 2008) minat adalah suatu ketertarikan dalam diri seseorang untuk menyenangi sesuatu objek. (Crow and Crow, 1993) menyebutkan bahwa minat dapat mendorong seseorang untuk terlibat secara aktif pada suatu objek apabila individu menaruh minat pada sesuatu hal. Sehingga dapat disimpulkan indikator dalam minat melanjutkan studi yakni adanya keinginan, adanya pengetahuan dan informasi, perhatian yang lebih besar, dan perasaan senang dan ketertarikan pada melanjutkan studi S2. (Djaali, 2012)

Hal ini tebukti saat melakukan observasi penelitian di Universitas Negeri Surabaya. Secara umum ditemukan beraneka ragam minat mahassiswa dalam melanjutkan studi ke jenjang S2. Tidak sedikit mahasiswa yang ingin 
melanjutkan studi S2 karena mereka berpikiran bahwa pendidikan sangatlah penting untuk masa depan, dan untuk meningkatkan jenjang karir. Tetapi tidak sedikit pula mahasiswa yang setelah lulus langsung ingin bekerja saja. Karena mereka beranggapan bahwa untuk melanjutkan studi ke jenjang S2 membutuhkan biaya yang cukup banyak. Akan tetapi ada mahasiswa yang berminat melanjutkan studi S2 namun mereka mencari beasiswa terlebih dahulu guna membiayai pendidikannya. Hal ini dapat membuktikan bahwa sesungguhnya minat mahasiswa untuk melanjutkan studi cukuplah tinggi namun disamping itu, biaya untuk melanjutkan studi cukup tinggi.

Sehingga rumusan masalah dalam penelitian ini : (1) adakah pengaruh status sosial ekonomi orang tua terhadap minat melanjutkan studi S2 mahasiswa fakultas ekonomi 2014 Unesa. (2) adakah pengaruh prestasi akademik terhadap minat melanjutkan studi S2 mahasiswa fakultas ekonomi 2014 Unesa.

\section{METODE}

Penelitian ini menggunakan pendekatan asosiatif dan jenis penelitiannya kuantitatif. Penelitian ini dilakukan di Unesa. Populasi pada

\begin{tabular}{|l|l|l|}
\hline No. & Progam Studi & Jumlah \\
\hline 1 & S1 P. Ekonomi & 27 \\
\hline 2 & S1 P. Akuntansi & 29 \\
\hline 3 & S1 P. Administrasi Perkantoran & 29 \\
\hline 4 & S1 P. Tata Niaga & 29 \\
\hline 5 & S1 Manajemen & 75 \\
\hline 6 & S1 Akuntansi & 37 \\
\hline 7 & D3 Akuntansi & 17 \\
\hline 8 & S1 Ekonomi Islam & 27 \\
\hline 9 & S1 Ekonomi & 0 \\
\hline \multicolumn{2}{|c|}{ JUMLAH } & 270 \\
\hline
\end{tabular}

penelitian ini yakni mahasiswa fakultas ekonomi angkatan 2014 sebanyak 827 mahasiswa. Teknik sampling yang digunakan simple random sampling. Dengan responden sebanyak 270, berikut tabel sampel.

Dalam penelitian ini, menggunakan teknik pengumpulan data dengan kuisioner dan dokumentasi. Kuisioner dalam penelitian ini terdiri dari 15 item pernyataan untuk variabel X1, IPK mahasiswa (X2) dan 20 item pernyataan Variabel Y. Teknik analisis data yang digunakan yakni: (1) Transformasi data skor menjadi data skala, (2) Uji asumsi klasik (uji normalitas, uji multikolinearitas, dan uji heteroskedastisitas), (3) Analis regresi linier berganda, (4) Hipotesis statistik.

\section{HASIL DAN PEMBAHASAN \\ Hasil Penelitian}

Tabel 1. Hasil Uji Regresi

Coefficients $^{\mathrm{a}}$

\begin{tabular}{|c|c|c|c|c|c|}
\hline \multirow[t]{2}{*}{ Model } & \multicolumn{2}{|c|}{$\begin{array}{l}\text { Unstandardized } \\
\text { Coefficients }\end{array}$} & \multirow{2}{*}{$\begin{array}{c}\begin{array}{c}\text { Standardize } \\
\mathrm{d} \\
\text { Coefficients }\end{array} \\
\text { Beta }\end{array}$} & \multirow[t]{2}{*}{$\mathrm{T}$} & \multirow[t]{2}{*}{ Sig. } \\
\hline & B & Std. Error & & & \\
\hline (Constant) & $-18,525$ & 11,790 & & $-1,571$ & , 117 \\
\hline $\begin{array}{cc} & \text { Prestasi } \\
1 & \text { Akademik (X2) }\end{array}$ & 11,360 & 3,048 & , 179 & 3,727 & ,000 \\
\hline $\begin{array}{c}\text { Status Sosial } \\
\text { Ekonomi (X1) }\end{array}$ & ,969 & ,075 & ,622 & 12,973 & ,000 \\
\hline
\end{tabular}

Dari hasil analisis regresi linier berganda diatas, diketahui bahwa:

$$
\begin{gathered}
Y=-\beta 0+\beta 1 X 1+\beta 2 X 2+\beta 3 X 3+\mu \mathrm{i} \\
Y=-18,525+11,360 X 1+0,969 X 2+\mu \mathrm{i} \\
\text { Dari persamaan regresi diatas dapat }
\end{gathered}
$$
ditemukan :

1. Konstanta (a) : $-18,525$.

2. Nilai koefisien Status Sosial (X1) sebesar 11,360 .

3. Nilai koefisien Prestasi Akademik (X2) sebesar 0,969 .

Tabel 2. Hasil Uji T

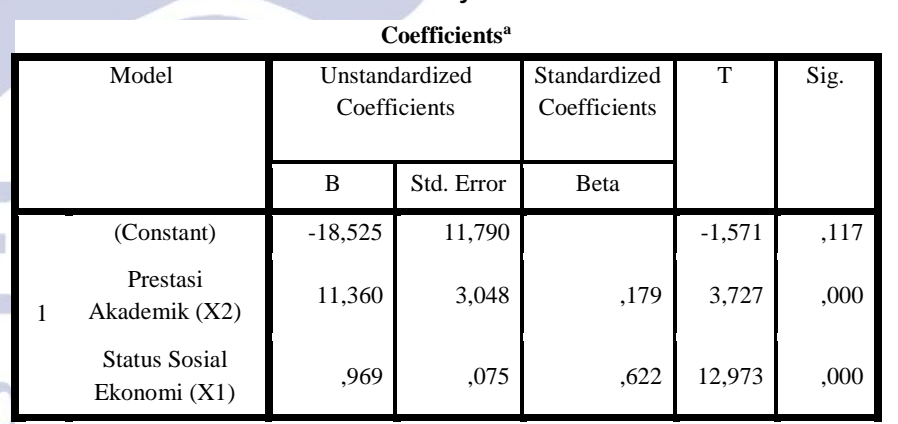

Sumber : data diolah peneliti, 2019

Berdasarkan hasil output SPSS pada Tabel 2 diketahui nilai signifikansi (Sig.) sebesar $0,000<$ probabilitas 0.05 , maka :

1. Diduga terdapat pengaruh yang positif antara (X1) terhadap (Y), dengan koefisien sebesar 11,360 dan tingkat sig. $0,000<0,05$ maka hasilnya Signifikan (positif).

2. Diduga ada pengaruh positif antara (X2) Terhadap Y, dengan koefisien sebesar 0,969 dan tingkat sig. $0,000<0,05$ maka hasilnya Signifikan (positif). 
Analisis regresi linier berganda diketahui persamaan regresinya yakni $\mathrm{Y}=$ $18,525+11,360 \mathrm{X} 1+0,969 \mathrm{X} 2$. Nilai (a) : 18,525 menunjukkan bahwa jika tidak ada Status sosial ekonomi orang tua (X1), dan prestasi akademik (X2) maka minat melanjutkan stdi S2 (Y) sebesar -18,525 dan nilai koefisien regresi (b) X1 sebesar 11,360 dan koefisien regersi X2 sebesar 0,969 .

\section{Pembahasan}

1. Pengaruh Status Sosial Ekonomi Orang Tua terhadap Minat Melanjutkan Studi S2 Mahasiswa Fakultas Ekonomi Unesa.

Berdasarkan hasil penelitian dapat diketahui bahwa variabel Status Sosial Ekonomi Orang Tua (X1) terhadap Minat Melanjutkan Studi S2 Mahasiswa (Y) diperoleh nilai koefisien regresi (b1) sebesar 0,969. Pada taraf signifikansi 5\% dapat diketahui $\mathrm{T}_{\text {hitung }} 12,973$ dengan nilai signifikansi sebesar 0,00 , karena koefisien mempunyai nilai positif dan nilai signifikansi (p) $<0,05$. Sehingga, apabila status sosial ekonomi orang tua semakin tinggi maka minat melanjutkan studi ke S2 akan tinggi pula, dan juga sebaliknya.

Hasil tersebut sesuai dengan teori yang diungkapkan (Slameto, 2010), yakni Status sosial ekonomi orang tua dapat mempengaruhi minat melanjutkan studi ke perguruan tinggi. Dalam membentuk karakter anak yang mempunyai pengaruh besar adalah kondisi sosial ekonomi orang tua. Kesempatan semakin luas bagi yang mempunyai keadaan ekonomi yang cukup untuk mengembangkan potensi pendidikan anaknya. Sedangkan bagi orang tua yang mempunyai keadaan ekonomi yang rendah tentu mempunyai kendala dalam mengembangkan potensi pendidikannya. Dalam ilmu ekonomi disebutkan bahwa semakin besar kebutuhan yang dapat terpenuhi apabila mempunyai pendapatan yang tinggi, sebaliknya kebutuhan tidak dapat terpenuhi dikarenakan mempunyai pendapatan yang rendah. Artinya yakni semakin tinggi pendapatan ekonomi maka fasilitas pendidikan tentu akan terpenuhi.

Dan (Elizabeth B. Hurlock, 2006) menyebutkan bahwa orang akan cenderung memperluas minatnya apabila kedaan status sosial ekonomi mencukupi.. Misalnya melanjutkan pendidikan ke jenjang yang lebih tinggi. Karena keadaan status sosial ekonomi orang tua yang baik akan berpengaruh positif terhadap penyediaan fasilitas belajar untuk anak.. Penelitian ini sesuai dengan penelitian (Nike Pratiwi Suciningrum, 2015) "Pengaruh Status Sosial Ekonomi Orang Tua, Dan Motivasi Belajar Terhadap Minat Melanjutkan Studi Ke Perguruan Tinggi Pada Kelas XI Di SMA Pusaka 1 Jakarta." Hasil penelitian ini mengatakan bahwa terdapat pengaruh positif dan signifikan status sosial ekonomi orang tua dan minat melanjutkan studi ke perguruan tinggi.

Indikator status sosial ekonomi orang tua yang sangat berpengaruh yakni tingkat pendapatan orang tua. Artinya tingkat pendapatan orang tua sangat mempengaruhi adanya minat mahasiswa untuk melanjutkan studi S2, karena melanjutkan studi S2 sangatlah membutuhkan biaya yang tidak sedikit. Lalu selanjtnya yang indikator kepemilikan fasilitas, yang artinya dengan memiliki fasilitas yang menunjang tentu minat terhadap pendidikan juga tinggi. Lalu selanjutnya yang yakni indikator tingkat pendidikan,yang artinya dengan semakin tinggi tingkat pendidikan orang tua tentu dapat mendorong anaknya untuk menempuh pendidikan yang tinggi pula. Laluyang terakhir indikator yang mempengaruhi minat melanjutkan studi S2 yakni jenis rumah tinggal.

Dengan demikian dapat dikatakan bahwa status sosial ekonomi orang tua berpengaruh positif dan signifikan terhadap minat melanjutkan studi S2.

2. Pengaruh Prestasi Akademik Mahasiswa terhadap Minat Melanjutkan Studi S2 Mahasiswa Fakultas Ekonomi Unesa.

Berdasarkan hasil penelitian dapat diketahui bahwa variabel Prestasi Akademik Mahasiswa (X2) terhadap Minat Melanjutkan Studi S2 Mahasiswa (Y) memperoleh nilai koefisien regresi (b1) sebesar 11,360. Dan mempunyai $\mathrm{T}_{\text {hitung }}$ 3,727 dengan nilai signifikansi 0,00 . Sehingga prestasi akademik mahasiswa yang tinggi, minat melanjutkan studi ke S2 juga akan tinggi, begitu pula sebaliknya.

Menurut (Sumadi Suryabrata, 2008) prestasi akademik yakni pencapaian akhir dari hasil belajar dan dinyatakan dalam bentuk simbol tertentu atau angka. Maka dari itu baik siswa maupun orang lain dapat mengetahui prestasi akademik yang telah di capai. Oleh karena itu, prestasi akademik di kampus/ universitas 
merupakan hasil belajar akhir mahasiswa yang dilihat dari penguasaan pelajaran selama perkuliahan dalam kurun waktu tertentu, sehingga IPK bisa dijadikan hasil belajar akhir. (Elizabeth B. Hurlock, 2006) Keberhasilan / kegagalan suatu akademis dapat mempengaruhi minat terhadap pendidikan. Menurut (Oemar Hamalik, 2012) dengan adanya motivasi dapat merangsang minat belajar. (Slameto, 2003) bahwa minat adalah rasa keterikatan pada suatu aktifitas atau suatu hal. Hasil penelitian juga sesuai dengan (Tantri Arumsari, 2013) "Pengaruh Prestasi Belajar dan Status Sosial Ekonomi Orang Tua Terhadap Minat Siswa untuk Melanjutkan Studi ke Perguruan Tinggi." Penelitian ini mengatakan bahwa terdapat pengaruh positif dan signifikan dalam variabel prestasi akademik dengan minat melanjutkan studi ke perguruan tinggi.

Sehingga prestasi akademik mahasiswa dapat berpengaruh terhadap minat melanjutkan studi ke S2.

\section{PENUTUP}

\section{Simpulan}

Kesimpulan penelitian ini adalah status sosial ekonomi orang tua dapat berpengaruh positif dan signifikan terhadap minat melanjutkan studi S2 pada mahasiswa Fakultas Ekonomi Angkatan 2014 Unesa. Dengan kemampuan sosial ekonomi yang mencukupi (tingkat pendapatan orang tua, kepemilikan fasilitas yang menunjang, tingkat pendidikan orang tua, dan jenis rumah tinggal) maka minat seorang anak untuk melanjuktkan pendidikan ke jenjang lebih tinggi akan besar.

Prestasi akademik berpengaryh positif dan signifikan terhadap minat melanjutkan studi S2 pada mahasiswa Fakultas Ekonomi-Angkatan 2014 Unesa. Karena dengan keberhasilan akademis dapat mendorong seseorang untuk melanjutkan studinya ke jenjang lebih tinggi.

\section{Saran}

Berdasarkan hasil penelitian, saran bagi mahasiswa yang ingin melanjutkan studi S2 namun terhalang biaya, alangkah lebih baiknya mencari beasiswa untuk dapat melanjutkan studi ke jenjang yang lebih tinggi.

Bagi Mahasiswa yang ingin melanjutkan studi S2 namun prestasi akademik masih rendah, alangkah lebih baiknya memperbaiki prestasi akademiknya. Karena mahasiswa akan semakin berminat apabila prestasi akademiknya baik.

\section{DAFTAR PUSTAKA}

Abdulsyani. (2012). Sosiologi: Skematika Teori dan Terapan. Jakarta: PT Bumi Aksara.

Crow and Crow. (1993). Psikologi Pendidikan. Yogyakarta: Nur Cahaya.

Djaali. (2012). Psikologi Pendidikan. Jakarta: Bumi Aksara.

Elizabeth B. Hurlock. (2006). Psikologi Pembangunan. Jakarta: Erlangga.

Muhibbin Syah. (2011). Psikologi Pendidikan Dengan Pendekatan Baru Edisi Revisi. Bandung: PT Remaja Rosdakarya.

Nike Pratiwi Suciningrum. (2015). Pengaruh Status Sosial Ekonomi Orang Tua, Dan Motivasi Belajar Terhadap Minat Melanjutkan Studi Ke Perguruan Tinggi Pada Kelas XI Di SMA Pusaka 1 Jakarta. Pendidikan Ekonomi Dan Bisnis, 3.

Oemar Hamalik. (2012). Proses Belajar Mengajar. Jakarta: PT Bina Aksara.

Slameto. (2003). Belajar dan Faktor - faktor yang Mempengaruhinya. Jakarta: Rineka Cipta.

Slameto. (2010). Belajar dan Faktor-Faktor yang Mempengaruhinya. Jakarta: Rineka Cipta.

Sumadi Suryabrata. (2008). Psikologi Pendidikan. Jakarta: Raja Grafindo Persada.

Tantri Arumsari. (2013). Pengaruh Prestasi Belajar dan Status Sosial Ekonomi Orang Tua Terhadap Minat Siswa untuk Melanjutkan Studi ke Perguruan Tinggi. Pendidikan Ekonomi, 2. 